\title{
Assessment of acquired immune response to Rhipicephalus appendiculatus tick infestation in different goat breeds
}

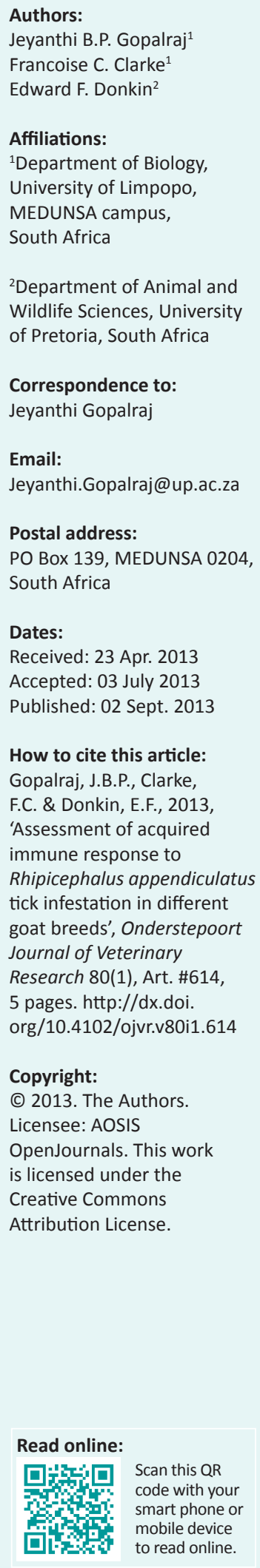

Changes in serum gamma globulin levels, numbers of replete female ticks and engorged tick mass were used as parameters to monitor the acquired immune response (antibody mediated immune response) elicited by Rhipicephalus appendiculatus adult tick infestations. Three consecutive Rhipicephalus appendiculatus adult tick infestations were applied to South African Indigenous goats (Nguni), Saanen goats and cross-bred goats (Saanen goats crossed with South African Indigenous goats [Nguni]) under laboratory conditions. During the three consecutive Rhipicephalus appendiculatus adult tick infestations the serum gamma globulin levels increased in all three breeds, whilst the mean replete female tick numbers and engorged tick mass decreased. Even though all three goat breeds exhibited an acquired immune response, the South African Indigenous goats (Nguni) response was significantly higher than that of the Saanen and cross-bred goats. However, the acquired immune response elicited by Saanen goats was significantly lower when compared with cross-bred goats.

\section{Introduction}

Small-scale South African farmers, especially those in communal areas, often depend on goats for meat and milk. Development programmes may include the introduction of milk goats for household milk production (Donkin \& Boyazoglu 2000). It would therefore be preferable if these goats were less susceptible to tick infestation. It has been shown that there are breed differences in goats towards resistance against heartwater, which is a major tick-borne disease (Donkin et al. 1992). It is therefore important to determine the potential of different goat breeds to acquire a natural resistance against tick infestation.

The present understanding of host-tick relationships and acquired resistance is based on work done with laboratory animals and different cattle breeds (Opdebeeck et al. 1988; Dipleou 1990; Rechav, Clarke, Els \& Dauth 1991). Many studies have been carried out to verify the acquisition of resistance by hosts when they are immunized by successive tick infestations (Jittapalapong et al. 2000a, 2000b; Monteiro \& Bechara 2008, Monteiro et al. 2011; Caperucci, Bechara \& CamargoMathias 2009, 2010; Veronez et al. 2010; Nunes, Bechara \& Camargo-Mathias 2011). It is generally accepted that the calves of all breeds are equally susceptible to tick infestation at birth (Hewetson 1972) and the ability to acquire a natural resistance varies from breed to breed (Dipeolu 1989; Spickett et al. 1989). It is characteristic of Asian Zebu calves (Bos indicus) to acquire a higher degree of tick resistance in a shorter period of time than the British breeds (Bos taurus) (Wagland 1978; Latif et al. 1991). However, resistance also fluctuates with season, photoperiod and rainfall (Sutherst \& Utech 1981). Studies of serum proteins have shown that the gamma globulin fraction is the only blood serum component that is affected by the development of resistance through tick infestation (Willadsen 1980; Rechav \& Dauth 1987).

Little is known about the tick-host relationship of different goat breeds. Resistance to tick feeding has been shown to be an acquired, immunologically mediated phenomenon in goats, associated with cutaneous basophilia to nymphs of the ixodid tick (Amblyomma cajennense) after repeated infestations (Monteiro \& Bechara 2008). Ixodid ticks remain attached to their hosts for extended periods of time, allowing ample opportunity for the development of immune mediated rejection and resistance mechanisms in the host (Champagne 1994). MacIvor and Horak (1987) reported that Angora goats were less resistant to tick infestation than Boer goats. Schwalbach, Bechara and Camargo-Mathias (2003) indicated that the Small East African Indigenous goat breed possesses a high resistance to tick infestation and higher tolerance to infestation effects than the exotic Toggenburg breed. Nyangiwe and Horak (2007) found that goats are good alternative hosts for most of the economically important ticks that infest cattle in South Africa. Since Rhipicephalus 
appendiculatus (R. appendiculatus) parasitises wild ungulates and livestock, and is common in goats (Bryson et al. 2002a, $2002 b$ ), it is important to assess the acquired immune responses of the same goat breeds, such as Saanen, South African Indigenous goats (Nguni) and cross-bred goats (Saanen X South African Indigenous goats) to infestations with this tick. The brown ear tick, R. appendiculatus, is a three-host tick of great economic importance as it acts as a vector for East Coast fever (cattle adaped Theileria parva), Corridor disease (buffalo associated Theileria parva), benign bovine theileriosis (Theileria mutans) and tick bite fever in man (Rickettsia conori).

\section{Material and methods}

Unfed adults of $R$. appendiculatus were used from a colony cycled on rabbits and maintained in the laboratory of the Department of Biology, Medunsa Campus, University of Limpopo at $25{ }^{\circ} \mathrm{C} \pm 1{ }^{\circ} \mathrm{C}$, at $75 \% \pm 5 \%$ Relative Humidity $(\mathrm{RH})$ and a photoperiod of approximately 12 hours of light and 12 hours of dark (12L:12D).

\section{Experimental animals}

The protocol of this study was approved by the Animal Ethics Committee at the Medunsa campus of the University of Limpopo. Sixteen month-old naïve (not exposed to any pathogens), healthy Saanen, South African Indigenous (Nguni) and cross-bred (Saanen $X$ South African Indigenous) goats were either kept in pens or in individual metabolic crates and supplied with adequate food (total mixed ration) and water.

\section{Acquired immune response assessments in goats Tick infestation}

Eight goats from each of the above mentioned goat breeds were infested three times with equal numbers of unfed $R$. appendiculatus males and females. So as not to over-infest the goats, three pairs of ticks were used per one $\mathrm{kg}$ host body mass. The unfed adult ticks were released into a linen bag glued to the shaven backs of the experimental animals, allowed to attach and feed and the engorged females were collected. Histamine release during feeding can increase vasopermeability and local discomfort in hosts, but can also lead to pruritus and intensified reflex grooming. Since grooming can dislodge ticks, grooming by the goats was limited through the application of leather collars and chaining to either side of the experimental cage, which allowed sufficient space for limited movement necessary for the goats to eat, drink and lie down. The goats were re-infested as soon as the engorged females of the previous infestation had all been collected. Replete females were collected on a daily basis and the individual mass of each was determined and recorded.

\section{Blood samples}

Blood samples of $5 \mathrm{~mL}$ from each goat for quantitative serum analysis were collected from the jugular vein in sterile heparin Vacutainer tubes (Lasec, South Africa) at the time of each infestation and again towards the end of each detachment period. Blood samples from a group of eight naïve animals from the same breed were taken and analysed as controls. The samples were allowed to clot at room temperature before the serum was retrieved for serological analysis.

\section{Electrophoresis and Serum proteins}

Blood serum protein levels were determined through electrophoresis. The serological analysis was performed on the day of collection by the Department of Chemical Pathology, University of Limpopo (Medunsa Campus). Serum protein-electrophoresis was done on an Agarose gel using the Paragon High Resolution Electrophoresis Kit (Beckman Instruments, Fullerton, California U.S.A) with a barbital buffer, $\mathrm{pH} 8.8$ (0.15 ionic strength). The membranes were scanned with an Appraise Densitometer (Beckman Instruments, USA) and separated into albumin $\alpha 1, \alpha 2, \beta$ and $\gamma$ globulin fractions.

\section{Statistical Analyses}

Comparing three or more treatment groups: the significance of differences in the means of engorged female mass and blood parameters were determined by subjecting the data to a One Way Analysis of Variance test (ANOVA) followed by Tukey HSD. Tests were used to indicate significance.

\section{Results \\ Gamma globulin levels}

The mean gamma globulin levels increased progressively after each tick infestation when compared to the uninfested control animals, as shown for South African Indigenous goats (Nguni) (Table 1).

The mean gamma globulin levels increased progressively after each tick infestation when compared to the uninfested control animals as shown for cross-bred (Table 2) goats.

The mean gamma globulin levels increased progressively after each tick infestation when compared to the uninfested control animals as shown for Saanen (Table 3) goats.

TABLE 1: Gamma globulin levels (g/L) in the serum of the test and control South African Indigenous goats (Nguni) before and after three consecutive infestations of Rhipicephalus appendiculatus adult ticks.

\begin{tabular}{lllll}
\hline Groups & $\begin{array}{l}\text { Pre infestation } \\
\text { Mean } \pm \text { SD }(\mathrm{g} / \mathrm{L})\end{array}$ & $\begin{array}{l}\text { 1st Post infestation } \\
\text { Mean } \pm \text { SD }(\mathrm{g} / \mathrm{L})\end{array}$ & $\begin{array}{l}\text { 2nd Post infestation } \\
\text { Mean } \pm \text { SD }(\mathrm{g} / \mathrm{L})\end{array}$ & $\begin{array}{l}\text { 3rd Post infestation } \\
\text { Mean } \pm \text { SD }(\mathrm{g} / \mathrm{L})\end{array}$ \\
\hline Control & $23.1 \pm 5.1$ & $21.3 \pm 3.1$ & $21.2 \pm 3.4$ & $21.3 \pm 3.7$ \\
Test group & $21.5 \pm 2.9$ & $25.5 \pm 3.2$ & $29.4 \pm 4.9$ & $p<0.7540$ \\
\hline
\end{tabular}

SD, Standard deviation; $\mathrm{g} / \mathrm{L}$, gram/Litre. 
TABLE 2: Gamma globulin levels ( $\mathrm{g} / \mathrm{L}$ ) in the serum of the test and control cross-bred goats (South African Indigenous goats X Saanen) before and after three consecutive infestations of Rhipicephalus appendiculatus adult ticks.

\begin{tabular}{lllll}
\hline Groups & $\begin{array}{l}\text { Pre-infestation } \\
\text { Mean } \pm \text { SD (g/L) }\end{array}$ & $\begin{array}{l}\text { 1st Post- infestation } \\
\text { Mean } \pm \text { SD (g/L) }\end{array}$ & $\begin{array}{l}\text { 2nd Post- infestation } \\
\text { Mean } \pm \text { SD (g/L) }\end{array}$ & $\begin{array}{l}\text { 3rd Post-infestation } \\
\text { Mean } \pm \text { SD (g/L) }\end{array}$ \\
\hline Control & $17.4 \pm 3.5$ & $16.5 \pm 3.2$ & $16.5 \pm 3.0$ & $16.2 \pm 3.0$ \\
Test group & $17.4 \pm 3.9$ & $20.7 \pm 3.2$ & $21.1 \pm 3.0$ & $p<0.90$ \\
\hline
\end{tabular}

SD, Standard deviation; $\mathrm{g} / \mathrm{L}$, gram/Litre.

TABLE 3: Gamma globulin levels $(\mathrm{g} / \mathrm{L}$ ) in the serum of the test and control Saanen goats before and after three consecutive infestations of Rhipicephalus appendiculatus adult ticks.

\begin{tabular}{lllll}
\hline Groups & $\begin{array}{l}\text { Pre-infestation } \\
\text { Mean } \pm \text { SD (g/L) }\end{array}$ & $\begin{array}{l}\text { 1st Post- infestation } \\
\text { Mean } \pm \text { SD }(\mathrm{g} / \mathrm{L})\end{array}$ & $\begin{array}{l}\text { 2nd Post- infestation } \\
\text { Mean } \pm \text { SD }(\mathrm{g} / \mathrm{L})\end{array}$ & $\begin{array}{l}\text { 3rd Post- infestation } \\
\text { Mean } \pm \text { SD }(\mathrm{g} / \mathrm{L})\end{array}$ \\
\hline Control & $26.4 \pm 1.5$ & $22.1 \pm 3.7$ & $24.3 \pm 4.1$ & $23.7 \pm 4.8$ \\
Test group & $26.1 \pm 2.3$ & $31.6 \pm 4.7$ & $30.6 \pm 5.2$ & $p<0.33$ \\
\hline
\end{tabular}

SD, Standard deviation; $\mathrm{g} / \mathrm{L}$, gram/Litre.

\section{Comparison between breeds}

Comparison between breeds in terms of increase in gamma globulin levels in the serum of South African Indigenous goats (Nguni), cross-bred goats and Saanen goats before and after each of three consecutive infestations with R. appendiculatus adult ticks is shown in Figure 1.

\section{Engorged female tick mass}

Figure 2 shows the mean engorged mass ( \pm SD) of female $R$. appendiculatus collected from South African Indigenous, cross-bred and Saanen goats after each of three successive infestations.

\section{Numbers of females completing the blood meal}

The decline in the numbers of $R$. appendiculatus females that completed their blood meal on the experimental South African Indigenous goats, cross-bred goats and Saanen goats are shown in Figure 3.

\section{Ethical considerations}

These experiments were conducted in agreement with the provisions enforced by the Research Ethics Committee (BP 06/98) and the Animal Ethics Committee of the Medunsa campus of the University of Limpopo. Goats were kept under controlled laboratory conditions in animal production unit at the experimental farm of Medunsa campus of the University of Limpopo with sufficient food, water, space and ventilation according to acceptable standards. As per university policy research data and records were maintained.

\section{Discussion}

\section{Gamma globulin levels}

An increase in the level of the protein globulins in the serum of the hosts indicates the development of acquired humoral immune responses (Rechav 1987; Rechav \& Dauth 1987). The higher levels of gamma globulin levels seen in the South African Indigenous goats (Nguni) were highly significant $(p<0.0001)$, indicating that three successive infestations of $R$. appendiculatus elicited a very strong acquired immune response. The cross-bred goats also exhibited significant increases in gamma globulin levels $(p<0.05)$ from preinfestation values and after the third infestation $(p<0.05)$,

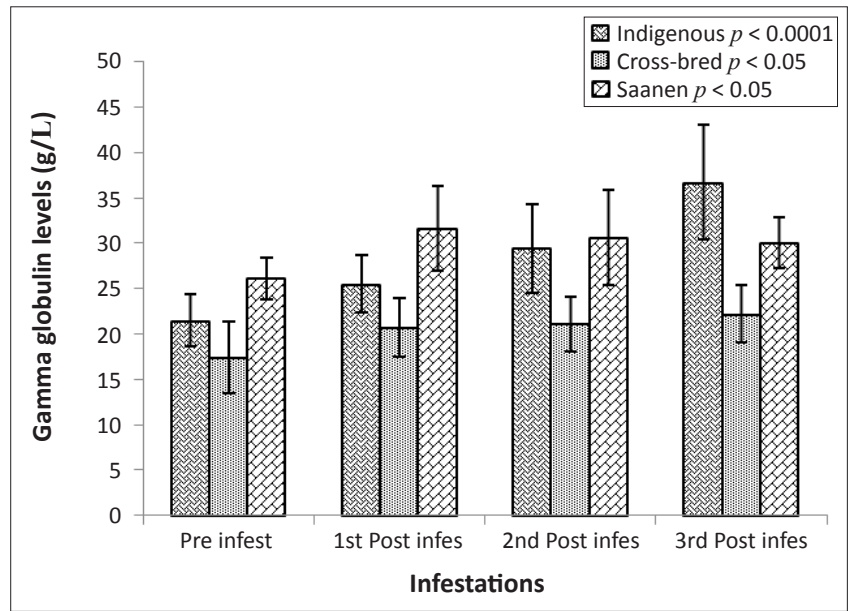

FIGURE 1: Increase in gamma globulin levels $(\mathrm{g} / \mathrm{L})$ in South African Indigenous goats (Nguni), cross-bred goats and Saanen goats before and after three consecutive infestations of Rhipicephalus appendiculatus adult ticks.

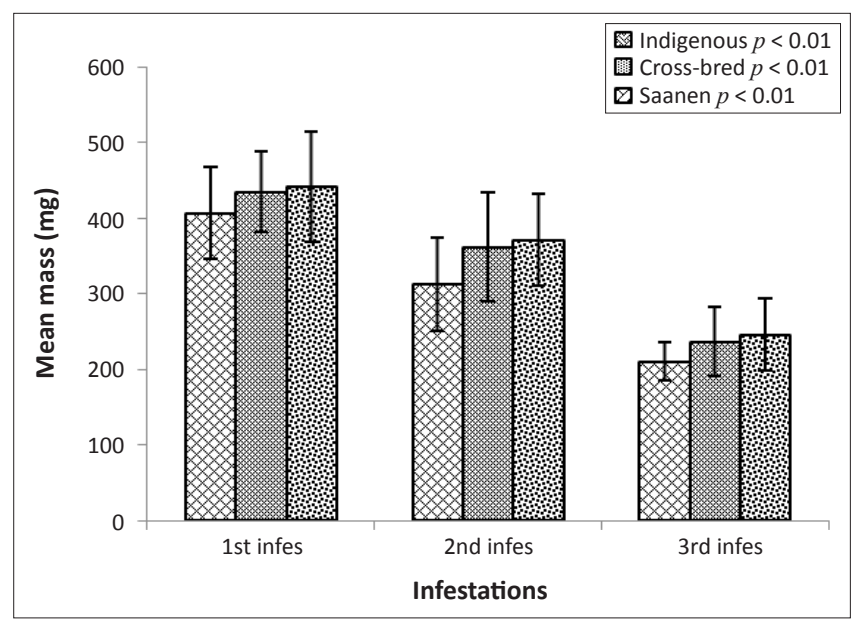

FIGURE 2: Mean engorged mass of female ticks (mg) recovered during three consecutive infestations of Rhipicephalus appendiculatus from South African Indigenous goats (Nguni), cross-bred and Saanen goats.

but not between the first and second infestations. Although significant, the acquired resistance elicited was less than the strong immune response elicited in the South African Indigenous goats (Nguni).

The Saanen goats also showed a concomitant increase in gamma globulin levels. The increases, although significant, indicated a relatively weak acquired response when 


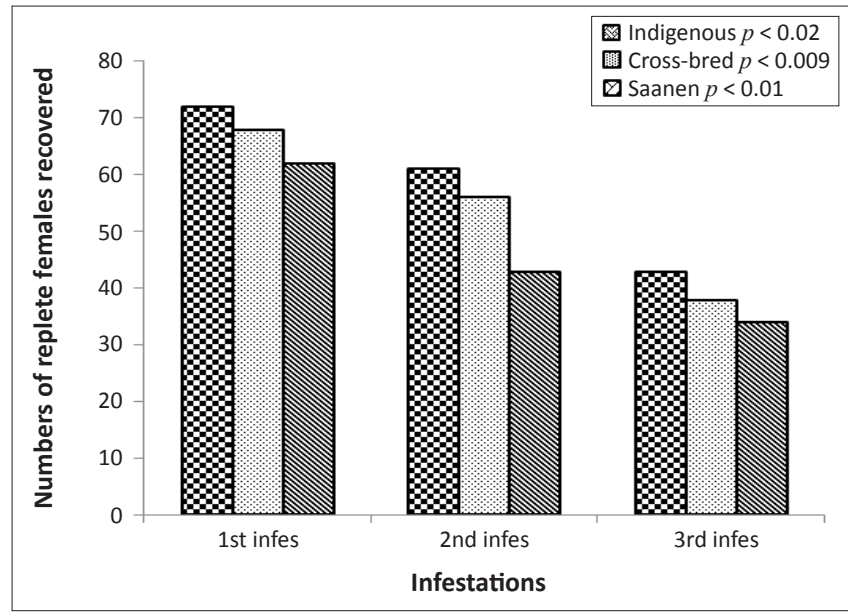

FIGURE 3: Replete females recovered during three consecutive infestations of Rhipicephalus appendiculatus from South African Indigenous goats (Nguni), cross-bred and Saanen goats.

compared to the response elicited in both the South African Indigenous and the crossbred goats mainly between the pre-infestation value and the values after the first and third infestations $(p<0.05)$.

Even though all three breeds exhibited increases in gamma globulin levels to some degree when compared to their preinfestation values, they were relatively high for the Saanen goats compared to the South African Indigenous goats and the cross-bred goats $(p<0.0001)$. This gamma globulin level was statistically significantly higher in the Saanen goats compared to the crossbred goats $(p<0.01)$ as well as in the Saanen compared to the South African Indigenous goats $(p<0.05)$; this implys that a Saanen goat has a strong immune system compared to the South African Indigenous goats and cross-bred goats.

\section{Engorged female tick mass}

The mean engorgement mass was found to be a consistently reliable indicator of the effect of an immune response on tick feeding success in laboratory animals (Heller-Haupt, Varma \& Langi 1981).

Three repeated infestation of South African Indigenous goats with adult $R$. appendiculatus ticks resulted in a highly significant decline of the mean engorgement mass of female ticks $(p<0.01)$. This was also true for the cross-bred goats $(p<0.01)$ as well as for the Saanen goats $(p<0.01)$. The difference between the mean engorged mass of the females from the first and second infestation was not significant, but the difference between the second and third infestation was significant, as was the difference after the first infestation when compared to the third infestation $(p<0.01)$. There were no significant breed differences in engorged female $R$. appendiculatus tick mass.

\section{Numbers of females completing the blood meal}

As only a few females complete their blood meal successfully on an immune host (Brown 1985), the number of ticks recovered from goats after each infestation were also used as an indication of immune response.
The numbers of engorged female ticks collected from all three goat breeds decreased with every infestation. Repeated infestation of South African Indigenous goats with adult $R$. appendiculatus ticks resulted in a significant decline in replete female tick numbers $(p<0.02)$ from the first and third infestation tick yield $(p<0.05)$.

Numbers of replete female ticks recovered from crossbred goats during three consecutive infestations also decreased significantly from first to the third and last infestation $(p<0.01)$.

The numbers of engorged $R$. appendiculatus females recovered from the Saanen goats after three subsequent infestations also showed a significant decrease in tick yield between the first and last infestation $(p<0.01)$. Although the engorged $R$. appendiculatus female tick numbers declined between infestations, the difference was not significant between breeds $(p<0.97)$.

\section{Conclusion}

During the three consecutive infestations the serum gamma globulin levels increased significantly $(p<0.0001)$ for all of the goat breeds, whilst the mean replete tick mass and the number of replete females collected decreased progressively. Even though all the breeds elicited an acquired immune response, the South African Indigenous goats (Nguni) developed a significantly higher level of acquired immunity $(p<0.01)$ compared to the Saanen goats and cross-bred goats, as measured by serum gamma globulin levels. The difference in mean gamma globulin levels between Saanen goats and the cross-breeds implies that the acquired immune response of the Saanen goats was lower when compared with crossbred goats $(p<0.0001)$.

\section{Acknowledgement}

This project was funded by the Medunsa campus of the University of Limpopo. Financial assistance by MEDUNSA for this research is highly acknowledged.

\section{Competing interests}

The authors declare that they have no financial or personal relationship(s) that may have inappropriately influenced them in writing this article.

\section{Authors' contributions}

F.C.C. (University of Limpopo, MEDUNSA campus) was my supervisor and E.F.D. (University of Pretoria) was my co-supervisor. J.B.P.G. (University of Limpopo, MEDUNSA campus) was involved in the design of study and in the sequence alignment. F.C.C. was involved in the project design and co-ordination. F.C.C. and E.F.D. participated in the experimental design. J.B.P.G. conducted all of the experiments and collected the data. Statistical data analysis and interpretation of the graphs were done by J.B.P.G. During the interpretation of results both F.C.C. and E.F.D. provided conceptual and intellectual contributions. J.B.P.G. drafted the manuscript. E.F.D. was involved with the integration of the breed difference assessment into the manuscript. 


\section{References}

Brown, S.J., 1985, 'Immunology of acquired resistance to ticks', Parasitology Today 1 166-171. http://dx.doi.org/10.1016/0169-4758(85)90175-9

Bryson, N.R., Tice, G.A., Horak, I.G., Stewart, C.G. \& Du Plessis, B.J.A., 2002a, 'Ixodid ticks on cattle belonging to small-scale farmers at four communal grazing areas in South Africa', Journal of the South African Veterinary Association 73, 98-103. PMid:12515294

Bryson, N.R., Tice, G.A., Horak, I.G., Stewart, C.G. \& Du Plessis, B.J.A., 2002b, 'Ixodid ticks on indigenous goats owned by small-scale farmers in four communal grazing areas in South Africa', Journal of the South African Veterinary Association 73 26-30. PMid:12088070

Caperucci, D., Bechara, G.H. \& Camargo-Mathias, M.I., 2009, 'Histopathology and ultrastructure features of the midgut of adult females of the tick Amblyomma cajenne Fabricius, 1787 (Acari: Ixodidae) in various feeding stages and submitted to three infestations', Ultrastructural Pathology 33(6), 249-259. http://dx.doi. org/10.3109/01913120903296945, PMid:19929171

Caperucci, D., Bechara, G.H. \& Camargo-Mathias, M.I., 2010, 'Ultrastructure features of the midgut of the female adult Amblyomma cajennense ticks Fabricius, 1787 (Acari: Ixodidae) in several feeding stages and subjected to three infestations Micron 41(7), 710-721. http://dx.doi.org/10.1016/j.micron.2010.05.015 PMid:20580564

Champagne, D.E., 1994, 'The role of salivary vasodilators in blood feeding and parasite transmission', Parasitology Today 10(11), 430-433. http://dx.doi.org/ 10.1016/0169-4758(94)90173-2

Dipeolu, O.O., 1989, 'Research on ticks of livestock in Africa; review of the trends, advances and milestones in tick biology and ecology in the decade 1980-1989', Insect Science and its Application 10, 741-750.

Dipeolu, O.O., 1990, 'Expression and quantification of degrees of resistance by rabbits to infection with Rhipicephalus sanguineus (L), Dermacentor variabilis (Say) and Amblyomma maculatum (Koch), (Acari: Ixodidae)', Insect Science and its application 11, 235-243.

Donkin, E.F. \& Boyazoglu, P.A., 2000, 'Milk production from goats for households and small-scale farmers in South Africa', Proceedings 7th International Conference on small-scale farmers in South Africa', Proceedin
Goats, France, 15-21 May 2000, pp. 324-326.

Donkin, E.F., Stewart, C.G., Macgregor, R.G., Els, H.C., Ramsay, K.A. \& Boyazoglu, P.A., 1992, 'Resistance of indigenous and crossbred goats to heartwater (Cowdria ruminantium)', 5th International Conference on Goats, Delhi, India, secondto 8th March 1992, in Recent Advances in Goat Production, pp. 1716-1719.

Heller-Haupt, A., Varma, M.G.R. \& Langi, A.O., 1981, 'Acquired resistance to ixodid ticks in laboratory animals', Transactions of the Royal Society of Tropical Medicine and Hygiene 75, 147-148. http://dx.doi.org/10.1016/0035-9203(81)90048-1

Hewetson, R.W., 1972, 'The inheritance of resistance by cattle to the cattle tick', Australian Veterinary Journal 48, 299-303. http://dx.doi.org/10.1111/j.17510813.1972.tb05161.x, PMid:5068812

Jittapalapong, S., Stich, R.W., Gordon, J.C., Wittum, T.E. \& Barriga, O.O., 2000a 'Performance of female Rhipicephalus sanguineus (Acari: Ixodidae) fed dogs exposed to multiple infestations or immunization with tick salivary gland or midgut tissues', Journal of Medical Entomology 37, 601-611. http://dx.doi. org/10.1603/0022-2585-37.4.601, PMid:10916303

Jittapalapong, S., Stich, R.W., Gordon, J.C., Bremer, C.A. \& Barriga, O.O., 2000b, 'Humoral immune response of dogs immunized with salivary gland, midgut, or repeated infestations with Rhipicephalus sanguineus', Annals of the New York Academy of Sciences 916, 283-288. http://dx.doi.org/10.1111/j.1749-6632.2000. tb05302.x, PMid:11193634
Latif, A.A., Nokoe, S., Punyua, D.K. \& Capstick, P.R., 1991, 'Tick infestations on Zebu cattle in western Kenya: Ouantitative assessment and host resistance', Journal of Medical Entomology 28, 122-126. PMid:2033603

Maclvor, K.M., De, F. \& Horak, I.G., 1987, 'Foot abscess in goats in relation to the seasonal abundance of adult Amblyomma hebraeum and adult Rhipicephalus glabroscutatum (Acari: Ixodidae)', Journal of the South African Veterinary Association, September 113-118. PMid:3508202

Monteiro, G.E.R. \& Bechara, G.H., 2008, 'Cutaneus basophilia in the resistance of goats to Amblyomma cajennense nymphs after repeated infestations', Annals of the New York Academy of Sciences 1149, 221-225. http://dx.doi.org/10.1196/ annals.1428.026, PMid:19120216

Monteiro, G.E.R., Bechara, G.H., Franzin, A.M. \& Miranda Santos, I.K.F., 2011, 'Antigenpresenting in draining lymph nodes of goads repeatedly infested by the Cayenne tick Amblyomma cajennense nymphs', Experimental and Applied Acarology 53 63-69. http://dx.doi.org/10.1007/s10493-010-9380-x, PMid:20596885

Nyangiwe, N. \& Horak, I.G., 2007, 'Goats as alternative hosts of cattle ticks', Onderstepoort Journal of Veterinary Research 74, 1-7. http://dx.doi.org/10.4102/ ojvr.v74i1.133, PMid:17708147

Nunes, P.H., Bechara, G.H. \& Camargo-Mathias, M.I., 2011, 'Secretory process of salivary glands of female Amblyomma cajennense (Acari: Ixodidae) ticks fed on resistant rabbits', Experimental and Applied Acarology 53, 179-187. http://dx.doi. org/10.1007/s10493-010-9388-2, PMid:20711802

Opdebeeck, J.P., Wong, J.Y.M., Jackson, L.A. \& Dobson, C., 1988, 'Hereford cattle immunized and protected against Boophilus microplus with soluble and membrane-associated antigens from the midgut of ticks', Parasite immunology 10, 405. http://dx.doi.org/10.1111/j.1365-3024.1988.tb00230.x, PMid:3174172

Rechav, Y., 1987, 'Resistance of Brahman and Hereford cattle to African ticks with reference to serum gamma globulin levels and blood composition', Experimental \& Applied Acarology 3(3), 219-32. http://dx.doi.org/10.1007/BF01270458

Rechav, Y. \& Dauth, J., 1987, 'Development of resistance in rabbits to immature stages of the tick, Rhipicephalus appendiculatus (Acari: Ixodidae)', Medical and Veterinary Entomology 1, 177-183. http://dx.doi.org/10.1111/j.1365-2915.1987 tb00340.x, PMid:2485122

Rechav, Y., Clarke, F.C., Els, D.A. \& Dauth, J., 1991, 'Development of resistance in laboratory animals to adults of the tick Rhipicephalus evertsi evertsi', Medical and
Veterinary Entomology 5(1), 29-34. http://dx.doi.org/10.1111/j.1365-2915.1991. Veterinary Entomology 5(1),

Schwalbach, L.M.J., Greyling, J.P.C. \& David, M., 2003, 'The efficacy of a $10 \%$ aqueous Neem (Azadirachta indica) seed extract for tick control in small East African and Toggenburg female goat kids in Tanzania', South African Journal of Animal Science 33(2), 83-88.

Spickett, A.M., De Klerk, D., Enslin, C.B. \& Scholtz, M.M., 1989, 'Resistance of Nguni, Bonsmara and Hereford cattle to ticks in a bushveld region of South Africa', Onderstepoort Journal of Veterinary Research 56, 245-250. PMid:2626263

Sutherst, R.W., Zimmer K.E., Gutleb, A.C., Lyche, J.L \& Utech, K.B.W., 1981, 'Controlling livestock parasites with host resistance', in D. Pimentel (ed.), CRC Handbook of pest management in agriculture, Boca Raton, CRC, vol. 2, pp. 385-407.

Veronez, V.A., Castro, M.B., Bechara, G.H. \& Szabó, M.PJ., 2010, 'Histopathology of Rhipicephalus sanguineus (Acari: Ixodidae) ticks fed on resistant hosts' Experimental and Applied Acarology 50, 151-161. http://dx.doi.org/10.1007/ s10493-009-9286-7, PMid:19554460

Wagland, B.M., 1978, ' Host resistance to cattle tick (Boophilus microplus) in Brahman (Bos indicus) cattle II, The dynamics of resistance in previously unexposed and exposed cattle', Australian Journal of Agricultural Research 29, 395-400. http:// exposed cattle', Australian Journal
dx.doi.org/10.1071/AR9780395

Willadsen, P., 1980, 'Immunity to ticks', Advanced Parasitology 18, 293-313. http:// dx.doi.org/10.1016/S0065-308X(08)60402-9 